\title{
Pharmaciana
}

Vol.11, No.1, March 2021, Page. 39-48

ISSN: 2088 4559; e-ISSN: 24770256

DOI: $10.12928 /$ pharmaciana.v11i1.18063

\section{Gastroprotective effect of Canna edulis Ker. ethanolic extract in piroxicam-induced rats}

\author{
Dara Pranidya Tilarso ${ }^{1,2}$, Moch. Saiful Bachri ${ }^{* 1}$, Wahyu Widyaningsih ${ }^{1}$ \\ ${ }^{I}$ Department Pharmacology and Clinical Pharmay,' Faculty of Pharmacy, Universitas Ahmad Dahlan \\ Jl. Prof. Dr. Soepomo, S.H., Janturan, Yogyakarta, Indonesia \\ ${ }^{2}$ Departement of Pharmacy, STIKes Karya Putra Bangsa \\ Jl. Raya Tulungagung-Blitar KM 4, Tulungagung, East Java, Indonesia
}

Submitted: 25-09-2020 Reviewed: 21-01-2021 Accepted: 29-03-2021

\begin{abstract}
Medications derived from plants and pure natural ingredients have far lower side effects and risks than synthetic drugs. One side effect of piroxicam is irritation of the digestive tract. One of the therapeutic preventions to minimize peptic ulcers was utilizing Canna edulis Ker. This study aims to prove that ethanolic extract of Canna edulis Ker. can be used as an alternative to prevent piroxicaminduced peptic ulcers based on ulcer index parameters and the protection ratio. The rats were divided randomly into 6 groups consisting of 5 rats. The normal group was given food and water. The negative control group was given $0.5 \% \mathrm{CMC}-\mathrm{Na}$. The extract groups were given various doses of ethanolic extract of Canna edulis Ker. (50, 100, and $200 \mathrm{mg} / \mathrm{kg} \mathrm{BW})$. The positive control was given sucralfate at $360 \mathrm{mg} / \mathrm{kg} \mathrm{BW}$ dose. Rats were treated orally for 14 days. One hour after the treatment on the 14th day, all groups except group I were orally administered with piroxicam dissolved in $0.5 \%$ CMC-Na at $1.8 \mathrm{mg} / \mathrm{kg} \mathrm{BW}$ dose. Twenty-four hours later, animals were sacrificed, dissected, and their stomach organs were removed to analyze its number of ulcers. Ulcer observation was formed by giving a score and protection ratio. The mean ulcer index value was $0.33 \pm 0.58$ for $50 \mathrm{mg} / \mathrm{kg} \mathrm{BW}$ and $100 \mathrm{mg} / \mathrm{kg} \mathrm{BW}$ ethanol extract treatment groups, while the $200 \mathrm{mg} / \mathrm{kg}$ BW group showed $0.67 \pm 0.58$. The protection ratio was $83.33 \pm 28.87$ in $50 \mathrm{mg} / \mathrm{kg} \mathrm{BW}$ and $100 \mathrm{mg} / \mathrm{kg} \mathrm{BW}$ treatment groups, while $66.67 \pm 28.87$ was shown in the $200 \mathrm{mg} / \mathrm{kg}$ BW group. Canna edulis Ker. ethanolic extract has the gastroprotective ability by decreasing the index of gastric ulcers and increasing the protection ratio to the stomach of piroxicam-induced rats.
\end{abstract}

Keywords: Canna edulis Ker., ethanolic extract, gastroprotective, piroxicam

\footnotetext{
*Corresponding author:

Moch. Saiful Bachri

Department Pharmacology and Clinical Pharmay, Faculty of Pharmacy, Universitas Ahmad Dahlan

Jl. Prof. Dr. Soepomo, S.H., Janturan, Yogyakarta

Email: msaifulbachri@yahoo.co.id
} 


\section{INTRODUCTION}

Medications derived from plants and pure natural ingredients have far lower side effects and risks than synthetic drugs. One side effect of piroxicam is irritation of the digestive tract (gastritis). The prevalence of gastritis with a high clinical impact is commonly caused by nonsteroidal antiinflammatory drugs (NSAIDs). One of the therapeutic preventions to minimize peptic ulcers was utilizing Canna edulis Ker. Previous research had been done by utilizing simplicia powder, Canna starch, and glucomannan. The occurrence of gastrointestinal inflammation and hemorrhage can be reduced in the stomach of $450 \mathrm{mg} / \mathrm{kg} \mathrm{BW}$ aspirin-induced rats; an $81.13 \%$ increase in the protection ratio at simplex powder and Canna starch and a $58.49 \%$ increase at glucomannan treatments (Kusbandari, 2013). The Canna edulis Ker. contained flavonoids, polyphenols, and proanthocyanidin (Mishra et al., 2012). Flavonoids are known as antiulcer and antioxidants in the digestive tract, with efficacious cytoprotective ingredients by protecting the gastric mucosa against ulcerogenic agents through the free radical destruction mechanism and increased mucus production (O'Leary et al., 2004). Some compounds that are also known to treat stomach ulcers are alkaloids. Alkaloids reduce gastric acid secretion, increase mucus and alkali secretion, and improve gastric mucosal blood flow to cure and prevent stomach ulcers against irritant agents/factors (Falcão et al., 2008). The content of efficacious compounds in Canna edulis Ker. will be more effective if used in extract form. The extraction carried out can attract the compound's desired components by separating one or more of the existing source components based on a compound's polarity (Mukhriani, 2014). The resulting extract will achieve the desired therapeutic target by its activity and as an alternative in the use of Canna tuber preparations to reduce the risk of patient non-compliance, which can cause the severity of peptic ulcers in patients given NSAIDs. This study aims to prove that Canna edulis Ker. ethanolic extract can be used as an alternative to prevent piroxicam-induced peptic ulcers based on ulcer index parameters and the ratio of protection in the stomach.

\section{MATERIALS AND METHOD \\ Materials}

Wistar strain female rats with 150-200 g bodyweight, 6-8 weeks old, healthy condition were obtained from LPPT Gadjah Mada University Yogyakarta. Canna bulbs were obtained from Canna tuber farmers purchased through traders at the Ngemplak Tulungagung market. Piroxicam used in this research is pure piroxicam obtained from PT. Indofarma. The carrier (solvent) for the test solution was a $0.5 \%$ CMC-Na solution obtained from the Pharmacology Laboratory, Faculty of Pharmacy, Universitas Ahmad Dahlan. The rat feed used was AD II.

\section{Methods \\ Plant determination}

To ensure that the material used is Canna edulis Ker., plant determination was carried out in the Biology Laboratory, Biology Study Program, Universitas Ahmad Dahlan Yogyakarta.

\section{Extract preparations from Canna tubers}

The Canna tuber's skin was discarded or peeled and cleaned from impurities by washing using running water. The Canna tuber was cut into pieces with a thickness of 3-5 $\mathrm{mm}$, then were put into the oven at $60-70^{\circ} \mathrm{C}$. After drying, these pieces of tubers were pulverized using a blender. The Canna tuber powder was extracted by maceration using $96 \%$ ethanol solvent for three (3) days. Then the mixture was filtered with a Buchner funnel and thickened with a rotary evaporator. The viscous extract was dissolved in $0.5 \%$ CMC-Na at 50,100, and $200 \mathrm{mg} / \mathrm{kg}$ doses for the gastroprotective study. 


\section{Ethanol-free test of ethanol extract}

Ethanol extract of Canna edulis Ker. was added with $\mathrm{H}_{2} \mathrm{SO}_{4}$, then added again with $\mathrm{CH}_{3} \mathrm{COOH}$, and heated. The test results were declared ethanol-free (negative) if the ester odor could not be smelled (Zhang et al., 1990)

\section{TLC content determination of ethanol extract}

First, the ethanolic extract of Canna edulis Ker. was dissolved with $96 \%$ ethanol. After that, the GF 254 silica gel was activated in an oven for 30 minutes at a temperature of $140^{\circ} \mathrm{C}$. Heating was done to remove water vapor which could interfere with the absorption of the eluted. At the same time, the mobile phase was first saturated in the chamber before being used to elute the silica because the mobile phase would elute perfectly at saturated chamber conditions. After the GF 254 silica gel was activated, the test solution was placed on the TLC plate of silica gel GF 254 using a capillary tube. The first test solution was a flavonoid standard, the Quercetin's standard solution, and the second was a sample (ethanolic extract of Canna edulis Ker.). Next, the silica gel plate was eluted with a mobile phase of n-butanol-acetate acid-water (BAW) with a ratio of 4: 1: 5. Finally, the results obtained were identified under UV lamps of $254 \mathrm{~nm}$ and $366 \mathrm{~nm}$.

\section{Grouping and treatment in experimental animals for peptic ulcers}

This research began with submitting an ethical clearance request to the Committee of Research Ethics of Ahmad Dahlan University and passed the Ethical Clearance (ethic reference number: 011810128). The rats were maintained (at room temperature) on standard pellet diets and tap water. The rats were divided randomly into 6 groups consisting of 5 rats. The normal group was given food and water; the negative control was given $0.5 \% \mathrm{CMC}-\mathrm{Na}$; the extract groups were given various doses of Canna edulis Ker. ethanolic extract $(50,100$, and $200 \mathrm{mg} / \mathrm{kg} \mathrm{BW})$ and positive control group was given sucralfate at a $360 \mathrm{mg} / \mathrm{kg} \mathrm{BW}$ dose. Rats were treated orally for 14 days. One hour after the treatment on the 14th day, all groups except the normal group were orally administered with piroxicam dissolved in $0.5 \% \mathrm{CMC}-\mathrm{Na}$ at a dose of $1.8 \mathrm{mg} / \mathrm{kg}$. Twenty-four hours later, animals were sacrificed, dissected, and their stomach organs removed to analyze the stomach's number of ulcers (Pertiwi et al., 2016).

\section{Macroscopic observation of gastric ulcer}

The stomach was isolated to determine the number and size of lesions/ulcers formed on the gastric mucosa. The stomach was opened surgically in the largest arch (major curvature) and was cleaned with $0.9 \% \mathrm{NaCl}$ solution. Then, it was spread on the flat surface to observe the formed ulcers (Gusdinar et al., 2009). Ulcer observation was formed by giving: score 0 if the tissue has no pathological changes (normal); score 1 if there was $0-1 \%$ gastric mucosal bleeding; score 2 if there was 1-5\% bleeding; score 3 if there was 5-10\% bleeding; score 4 if there was a 10-15\% bleeding; and a score of 5 if there was bleeding $>15 \%$ of the gastric mucosal area. Meanwhile, the protection ratio was calculated based on the following formula:

$$
\% \text { protection ratio }=100 \%-\left[\frac{\text { UI treated control }}{\text { UI ulcer control }} \times 100 \%\right](\text { Saptarini, } 2011) .
$$

Note: $\mathrm{UI}=$ ulcer index

\section{Microscopic observation of gastric ulcer}

The stomach that had been taken was then washed with $0.9 \% \mathrm{NaCl}$. Then, it was put in a pot, weighed, then was put in a $10 \%$ formalin solution. The histopathological examination was done based on work procedures applied in the Pathology Laboratory, Faculty of Veterinary Medicine, Gadjah Mada University. Histopathological quantitative analysis was carried out by scoring each preparation based on the level of damage formed. This scoring method is a modified histopathological scoring 
method which was done by (Okatiranti, 2011). The results of observation histopathological can be seen in Table 1.

Table 1. Scoring of stomach damage on observation histopathological (Okatiranti, 2011)

\begin{tabular}{lc}
\multicolumn{1}{c}{ Damage Rate } & Score \\
\hline There are no pathological changes & 0 \\
There is congestion, edema, and inflammatory cell infiltration & 1 \\
There is erosion, congestion, edema, and inflammatory cell infiltration & 2 \\
There is bleeding, edema, and inflammatory cell infiltration & 3 \\
There is erosion, bleeding, edema, and inflammatory cell infiltration & 4 \\
\hline
\end{tabular}

\section{Data Analysis}

ImageJ analysis was used to see the percentage of ulcer area produced in the stomach. Data were expressed as mean \pm standard deviation and statistically evaluated using one-way analysis of variance, followed by Kolmogorov-Smirnov and Levene tests using SPSS software version 24. $P<0.05$ was considered significant.

\section{RESULT AND DISCUSSION}

The plant determination proved that the plant used in this research was Canna edulis Ker. The maceration used the extraction method because it was simply done by soaking, without heating, thus avoiding damage to the compound content (Dean, 2009). The solvent used in the extraction process was ethanol $96 \%$, which was selected based on the safety and ease level when evaporating (Khoiriyah, 2014). Nevertheless, the maceration method's disadvantage is that it requires a lot of solvents and no less than perfect extraction, so stirring is essential to optimize the method.

The extraction results obtained in this study were tested for ethanol. This ethanol-free test was carried out to free the extract from ethanol to obtain a pure extract without any contamination. Ethanol could cause damage to the gastric mucosa, which would not cause false negatives in the treatment of the sample. The results of the ethanol-free test of Canna edulis Ker. ethanolic extract indicated that the extract was ethanol-free so that it can be concluded that an extract that can be used for the next stage was obtained. The results of the ethanol-free test can be seen in Table 2 .

Table 2. Ethanol-free test from the ethanolic extract of Canna edulis Ker. (Zhang et al., 1990)

\begin{tabular}{|c|c|c|}
\hline Identification & Procedures & Results \\
\hline Ethanol-free test & $\begin{array}{c}\text { Extract }+\mathrm{H}_{2} \mathrm{SO}_{4}+\mathrm{CH}_{3} \mathrm{COOH} \\
\rightarrow \text { heated }\end{array}$ & No smell of ester \\
\hline
\end{tabular}

In the experimental results of UV observation of $254 \mathrm{~nm}$, brown spots were obtained in the sample solution with an Rf value of 0.87 , which was different from the Quercetin standard solution, which shows a $0.75 \mathrm{Rf}$ value. Different spots were found on $366 \mathrm{~nm}-\mathrm{UV}$ observation; there were four (4) purple spots with Rf values of $0.15,0.4,0.68$, and 0.87 , and brown quercetin spots with an $\mathrm{Rf}$ value of 0.75 . The results of TLC determination can be seen in Figure 1. 


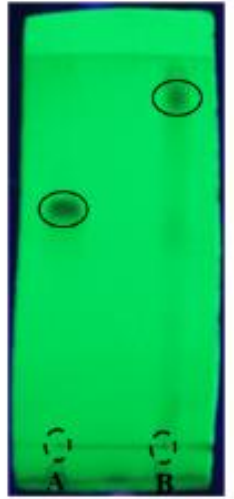

UV $254 \mathrm{~nm}$

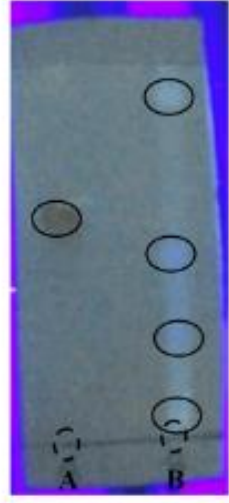

UV $366 \mathrm{~nm}$

Figure 1. TLC content determination of Canna edulis Ker. extract

Note : (A) Quercetin standart

(B) Ethanolic extract of Canna edulis Ker.

The TLC test determination results of this study showed that the ethanolic extract of Canna tuber did not contain Quercetin based on the resulting Rf value and the fluorescent difference at 254 $\mathrm{nm}-\mathrm{UV}$ and $366 \mathrm{~nm}-\mathrm{UV}$. Dark spots occurred at Figure 1A (Quercetin standard) and fluorescence at Figure 1B (ethanolic extract of Canna edulis Ker.). It was suspected that the compounds contained in the Canna tuber extract were other flavonoid compounds that were more polar.

Analysis was carried out on six groups of test animals for 14 days. Observation of test animals was carried out on the 15th day by giving piroxicam as an ulcer-forming agent, which had been previously fasted for 24 hours to reduce the stomach contents to facilitate observation. It had been known before that NSAIDs could cause damage to the gastroduodenal mucosa through several mechanisms, including topical irritant effects on the epithelial and mucosal barrier, inhibiting prostaglandin synthesis, reducing blood flow to the gastric mucosa, and inhibiting superficial repair. Piroxicam is a potent NSAID and has gastrointestinal side effects like other NSAIDs (Wallace and Vong, 2008).

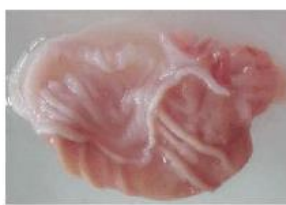

(A)

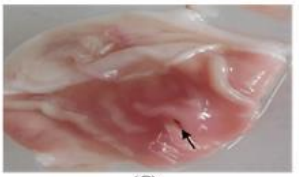

(C)

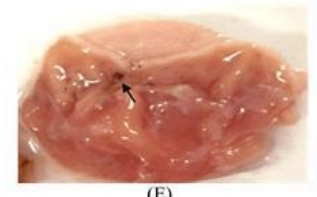

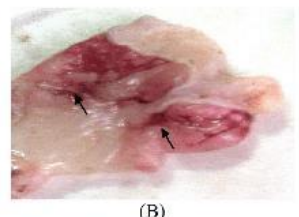

(B)
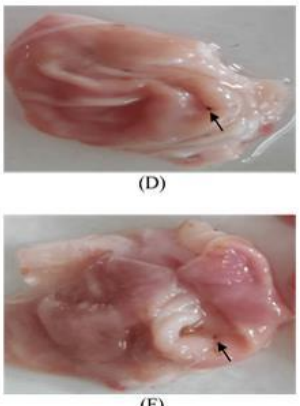

Figure 2. Macroscopic picture of gastric damage in piroxicam-induced rats (A) Normal (B) Negative control (C) $50 \mathrm{mg} / \mathrm{kg} \mathrm{BW}$ extract (D) $100 \mathrm{mg} / \mathrm{kg} \mathrm{BW}$ extract (E) $200 \mathrm{mg} / \mathrm{kg} \mathrm{BW}$ extract (F) Positive control (Sucralfate). Note: Black arrows indicate the presence of lesions and hyperemia 
Based on the evaluation results in Figure 2, it can be seen the level of gastric damage in each treatment group. Gastric features were obtained using ImageJ to determine the percentage of abdominal area that had increased bleeding by looking at dark spots compared to the normal group. Observations were made three (3) times with different subjects to avoid subjective assessments. The results of ImageJ analysis can be seen in Table 3.

Table 3. Percentage of abdominal area with bleeding

\begin{tabular}{ccc}
\hline Group & Dose $(\mathbf{m g} / \mathbf{k g ~ B W})$ & $\mathbf{X} \pm \mathbf{S D}(\boldsymbol{\%})$ \\
\hline Normal & - & $0.00 \pm 0.00^{*}$ \\
Negative (piroxicam) & 1.8 & $1.81 \pm 0.11$ \\
Extract & 50 & $0.48 \pm 0.10^{*}$ \\
& 100 & $0.46 \pm 0.27^{*}$ \\
Positive (Sucralfate) & 200 & $0.61 \pm 0.16^{*}$ \\
\hline
\end{tabular}

$*$ sig $<0.05$, there is a significant difference with negative control

Macroscopic analysis of the percentage of abdominal area that had increased hemorrhage was followed by area scoring. The obtained results showed the ulcer index and the ratio of protection in the stomach of piroxicam-induced rats. The results of ulcer index scoring and protection ratio can be observed in Table 4.

Table 4. Mean values of ulcer index score and protection ratio in piroxicam-induced rats treated with the ethanolic extract of Canna edulis Ker

\begin{tabular}{cccc}
\hline Group & Dose $(\mathbf{m g} / \mathbf{k g ~ B W})$ & Ulcer Index Score & Protection Ratio \\
\hline Normal & - & $0 \pm 0^{*}$ & $100 \pm 0^{*}$ \\
Negative (Piroxicam) & 1.8 & $2 \pm 0$ & $0 \pm 0^{* *}$ \\
Extract & 50 & $0.33 \pm 0.58^{*}$ & $83.33 \pm 28.87^{*}$ \\
& 100 & $0.33 \pm 0.58^{*}$ & $83.33 \pm 28.87^{*}$ \\
& 200 & $0.67 \pm 0.58^{*}$ & $66.67 \pm 28.87^{*}$ \\
Positive (Sucralfate) & 360 & $0 \pm 0^{*}$ & $100 \pm 0$ \\
\hline
\end{tabular}

$*$ sig $<0.05$, there is a significant difference with negative controls

Based on Table 4, it can be concluded that the entire treatment group of Canna edulis Ker. ethanolic extract showed a decrease in the ulcer index's mean value of the rats' stomachs compared to the negative control. However, the ulcer index's mean value of each treatment group of Canna edulis Ker. ethanolic extract showed a difference, where the lowest ulcer index value $(0.33 \pm 0.58)$ was found at $50 \mathrm{mg} / \mathrm{kg} \mathrm{BW}$ and $100 \mathrm{mg} / \mathrm{kg} \mathrm{BW}$ doses, while $200 \mathrm{mg} / \mathrm{kg} \mathrm{BW}$ dose showed $0.67 \pm 0.58$. The assessment of the ulcer index's mean values will affect the protection ratio. The calculation of protection ratios using the formula by (Saptarini, 2011) shows the existence of protection ratios in Canna edulis Ker. ethanolic extract treatment groups.

The averaged protection ratio results based on Table 4 were: the largest protection ratio was $83.33 \pm 28.87$, shown by the $50 \mathrm{mg} / \mathrm{kg}$ and $100 \mathrm{mg} / \mathrm{kg}$ BW treatment groups, while extract $200 \mathrm{mg} / \mathrm{kg}$ $\mathrm{BW}$ had an average value of the percent protection ratio of $66.67 \pm 28.87$. The analysis continued with a statistical test to see the differences that occurred in each treatment group. Mann-Whitney test results showed that the sucralfate treatment group showed no significant difference with the $50 \mathrm{mg} / \mathrm{kg}$ and $100 \mathrm{mg} / \mathrm{kg} \mathrm{BW}$ treatment group of Canna edulis Ker. ethanolic extract with a significance value of 0.317 ( $\mathrm{sig}>0.05$ ), along with $200 \mathrm{mg} / \mathrm{kg} \mathrm{BW}$ ethanolic extract treatment group with a significance value of 0.114 (sig>0.05). 
Based on the results of macroscopic observations made, it can be concluded that the Canna edulis Ker. ethanolic extract treatment group has a gastroprotective effect as indicated by a reduction in the abdominal area that had been bleeding, the decrease in ulcer index, and an increase in protection ratio percentage.

The microscopic analysis was carried out to observe microscopic gastric damage by performing histopathological examinations on rats' stomachs. Sliced preparations of gastric tissue were made for each treatment group for the histopathological examination. The examination results were qualitatively and quantitatively stated. The qualitative analysis can be seen in Figure 3.

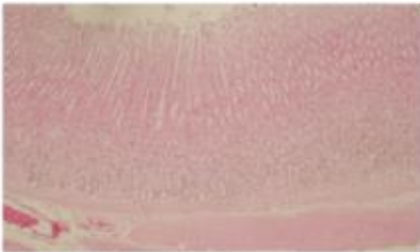

(A)

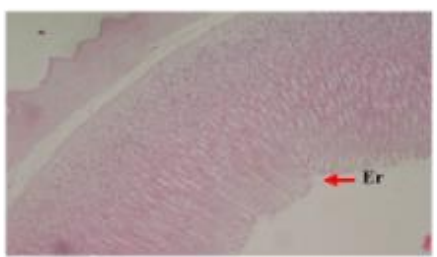

(C)

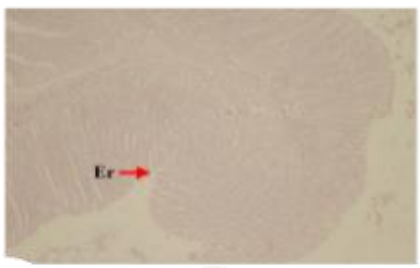

(E)

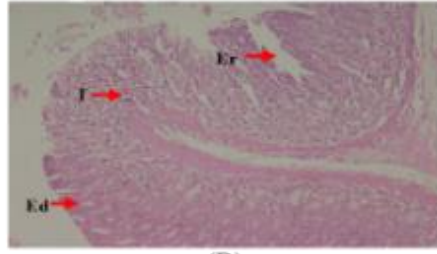

(B)

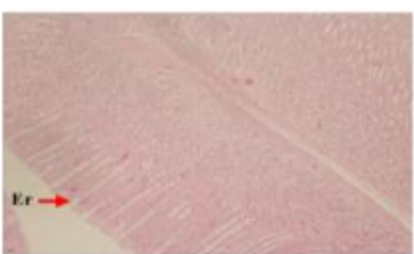

(D)

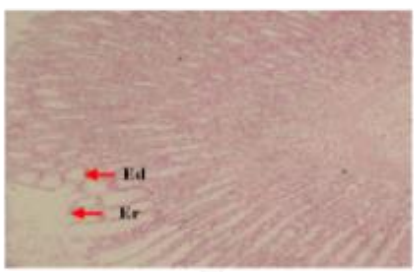

(F)

Figure 3. Histopathological Stomach Damage (A) Normal; (B) Negative control; (C) $50 \mathrm{mg} / \mathrm{kg} \mathrm{BW}$ extract; (D) $100 \mathrm{mg} / \mathrm{kg} \mathrm{BW}$ extract; (E) $200 \mathrm{mg} / \mathrm{kgBW}$ extract; (F) Positive control (Sucralfate). Note: Edema (Ed), Erosion (Er); Inflammatory cell infiltration (I). Hematoxilyn eosin staining, 100x magnification

Quantitative analysis was performed by scoring each preparation. The scoring results of observing the gastric damage level in each treatment group are presented in Table 5.

Table 5. Stomach damage score based on mean value total histopathological observation scoring in piroxicam-induced rats treated with Canna edulis Ker. ethanolic extract

\begin{tabular}{ccc}
\hline Group & Dose $(\mathbf{m g} / \mathbf{k g ~ B W})$ & $\mathbf{X} \pm \mathbf{S D}$ \\
\hline Normal & & $0.33 \pm 0.47^{*}$ \\
Negative (Piroxicam) & 1.8 & $1.67 \pm 0.47$ \\
Extract & 50 & $0.33 \pm 0.47^{*}$ \\
& 100 & $0.33 \pm 0.47^{*}$ \\
& 200 & $0.33 \pm 0.47^{*}$ \\
Positive (Sucralfate) & 360 & $1.00 \pm 0.00^{* *}$ \\
\hline
\end{tabular}

* sig <0.05, there was a significant difference with negative controls 
The qualitative test results of the histopathological imaging showed that all treatment groups showed pathological changes in the stomach. The microscopic image of the stomach is said to be normal if there were no signs of ulcers. In the normal group that was only given food and drink, it showed a picture of mild damage (mild infiltration) with a score of $0.33 \pm 0.47$, which was significantly different from the negative control with a significance value of 0.009 ( $\mathrm{sig}<0.05$ ). This might be due to external variables that cannot be controlled. During this study, it was suspected that the rats experienced severe stress due to the 15-day treatment period and other unknown reasons. Thus, the rats' stomachs acid increased excessively. Another reason might be due to the initial condition of the rats' stomachs that had been damaged.

This study's observations showed that inflammatory cell infiltration was found in almost all Canna edulis Ker. ethanolic extract treatment groups. The mean score of histopathological observations showed a value of $0.33 \pm 0.47$, significantly different from the negative control with a significance value of 0.009 ( $\mathrm{sig}<0.05$ ). The most dominant cell infiltration was in the mucosal layer. It was suspected that the lymphocyte infiltration is not due to pathological abnormalities. Several lymphocytes, plasma cells, neutrophils, and mast cells are commonly found in the mucosal layer under normal conditions. This is because the migration of inflammatory cells is a general response reaction to toxic substances that enter the body and is a pathophysiological reaction against harmful agents (Bain, 1991).

The histopathological imaging was carried out to strengthen the quantitative analysis results of ulcer index and protection ratio observations. The histopathological images presented that the Canna edulis Ker. ethanolic extract provided conditions for gastric repair by decreasing the ulcer index value and increasing the protection ratio. The most severe gastric damage occurred in the positive treatment group that was given sucralfate. This was different from the treatment group of Canna tuber ethanolic extract, which is a natural product. The body is relatively easier to digest drugs from natural ingredients in traditional medicine than synthetic materials because of their natural properties.

In general, the therapeutic effect will increase with increasing doses. However, it was not the case for Canna edulis Ker. ethanolic extract treatment groups. The description of macroscopic observations in the stomach of piroxicam-induced rats that showed a gastroprotective effect did not depend on increasing the dose (dose-dependent). The decrease in the ulcer index and the increase in the protection ratio did not increase linearly with increasing doses at extract $50 \mathrm{mg} / \mathrm{kg} \mathrm{BW}$ and 100 $\mathrm{mg} / \mathrm{kg} \mathrm{BW}$. This is because of the compounds contained in Canna edulis Ker. plants do not work independently to produce a cumulative effect (not parallel) (Kingsbury, 2001). Especially in the treatment dose of $200 \mathrm{mg} / \mathrm{kg} \mathrm{BW}$, the ulcer index reduction and an increase in the protection ratio are not as effective as in other doses. This allegedly happened because of the saturation factor of the extract at specific doses. Several components of active compounds in plants are simultaneously involved in therapy, thus enabling these active compound components to have a synergistic or antagonistic effect (Syahrir et al., 2016). Thus, the synergistic effect that occurs can increase concentration to the saturation point.

According to previous studies, Canna edulis Ker's protective mechanism was due to its flavonoids contents and cytoprotective effects. Flavonoids work by protecting the gastric mucosa against ulcerogenic agents through the free radical destruction mechanism, increased mucus production, and anti-secretory system (O'Leary et al., 2004). Alkaloids in Canna tuber ethanolic extract also work by a mechanism to reduce gastric acid secretion, increase mucus and alkaline secretion, and improve gastric mucosal blood flow to help healing and prevention of gastric ulcer against irritant agents/factors (Falcão et al., 2008). Tannin compounds are also known to have a gastroprotective effect that inhibits gastric secretion and local gastric mucosa protection (Ezaki et al., 1985).

Pharmaciana Vol. 11, No. 1, March 2021, Page.39 - 48 


\section{CONCLUSION}

Canna edulis Ker. ethanolic extract has the gastroprotective ability by decreasing the index of gastric ulcers and increasing the ratio of protection to the stomach of piroxicam-induced rats.

\section{REFERENCES}

Bain, S. (1991). Pathology of the Fischer Rat - Reference and Atlas. Pathology, 23(4), 368. https://doi.org/10.1016/s0031-3025(16)36070-6

Dean, J. R. (2009). Extraction techniques in analytical sciences. John Wiley \& Sons, Ltd. https://doi.org/10.1002/9780470682494

Ezaki, N., Kato, M., Takizawa, N., Morimoto, S., Nonaka, G., \& Nishioka, I. (1985). Pharmacological studies on Linderae umbellatae ramus, IV. Effects of condensed tannin related compounds on peptic activity and stress-induced gastric lesions in mice. Planta Medica, NO. 1(1), 34-38. https://doi.org/10.1055/s-2007-969386

Falcão, H. D. S., Leite, J. A., Barbosa-Filho, J. M., De Athayde-Filho, P. F., Chaves, M. C. D. O., Moura, M. D., Ferreira, A. L., De Almeida, A. B. A., Souza-Brito, A. R. M., Diniz, M. D. F. F. M., \& Batista, L. M. (2008). Gastric and duodenal antiulcer activity of alkaloids: A review. In Molecules (Vol. 13, Issue 12, pp. 3198-3223). Multidisciplinary Digital Publishing Institute (MDPI). https://doi.org/10.3390/molecules13123198

Gusdinar, T., Herowati, R., Kartasasmita, R. E., \& Adnyana, I. K. (2009). Synthesis and gastric ulcer protective activity of chlorinated quercetin. Indonesian Journal of Pharmacy, O(0), 163-169. https://doi.org/10.14499/INDONESIANJPHARM0ISS0PP163-169

Khoiriyah, S. (2014). Uji fitokimia dan aktivitas antibakteri Fraksi etil asetat, Kloroform dan Petroleum eter ekstrak metanol alga coklat Sargassum vulgare dari Pantai Kapong Pamekasan Madura. Alchemy: Journal of Chemistry, 3(2), 133-144

Kingsbury, J. M. (2001). Phytotoxicology. In Casarett \& Doull's (Ed.), Toxicology: the basic science of poisons (pp. 591-603). Macmillan Publishing Co

Kusbandari, A. (2013). Analisis kandungan karbohidrat dan nilai indeks glisemik serta aktivitas anti ulser dan anti kolesterol umbi ganyong (Canna edulis Ker.). Thesis, Fakultas Farmasi Universitas Gadjah Mada

Mishra, T., Das, A., \& Sen, A. (2012). Phytochemical screening and in vitro antioxidant profiling of solvent fractions of canna edulis ker gawler. Free Radicals and Antioxidants, 2, 13-20. https://doi.org/10.5530/ax.2012.2.5

Mukhriani. (2014). Ekstraksi, pemisahan senyawa, dan identifikasi senyawa aktif. Jurnal Kesehatan, VII(2), 361-367. https://doi.org/10.17969/agripet.v16i2.4142

O’Leary, K. A., De Pascual-Tereasa, S., Needs, P. W., Bao, Y. P., O’Brien, N. M., \& Williamson, G. (2004). Effect of flavonoids and Vitamin E on cyclooxygenase-2 (COX-2) transcription. Mutation Research - Fundamental and Molecular Mechanisms of Mutagenesis, 551(1-2), 245254. https://doi.org/10.1016/j.mrfmmm.2004.01.015

Okatiranti. (2011). Pengaruh pemberian ekstrak daun pegagan (Centella asiatica) pada ketahanan mukosa lambung (Gastroprotektif) tikus yang mengalami stres immobilisasi. Majalah Obat Tradisional, 16(2), 2011

Pertiwi, R., Bachri, M. S., \& Widyaningsih, W. (2016). Efek gastroprotektor ekstrak etanol umbi garut (Maranta arundinacea L.) terhadap indeks tukak lambung, rasio proteksi, ekspresi protein COX-2 dan gambaran histopatologis lambung pada tikus model tukak lambung. Thesis, Fakultas Farmasi Universitas Ahmad Dahlan.

Saptarini. (2011). Analisis rasio protektif antiulser sari buah pepino solanum muricatum aiton menggunakan mencit sebagai hewan coba. Majalah Obat Kesehatan, 16(2), 75-80

Syahrir, N. H. A., Afendi, F. M., \& Susetyo, B. (2016). Efek sinergis bahan aktif tanaman obat berbasiskan jejaring dengan protein target. Jurnal Jamu Indonesia, 1(1), 35-46.

Wallace, J. L., \& Vong, L. (2008). NSAID-induced gastrointestinal damage and the design of GIsparing NSAIDs. Current Opinion in Investigational Drugs (London, England: 2000), 9(11), 
1151-1156.

Zhang, J. F., Yan, C. D., Zhang, Y. Q., Gao, W. Z., \& Zhai, X. M. (1990). [Effect of scopolia drugs on the gastric mucosal lesion in rats]. Yao xиe xиe bao = Acta pharmaceutica Sinica, 25(2), 90-94 